\title{
Use of barley malt pomace in the production of fresh sausage
}

\section{Aproveitamento do bagaço de malte de cevada na produção de linguiça frescal}

\author{
Gerson Herrmann ${ }^{1}$, Claucia Fernanda Volken de Souza ${ }^{1,2 *}$ (D) \\ ${ }^{1}$ Centro de Ciências Exatas e Tecnológicas, Universidade do Vale do Taquari - Univates, Lajeado/RS - Brasil.
}

2Programa de Pós-Graduação em Biotecnologia, Universidade do Vale do Taquari - Univates, Lajeado/RS - Brasil.

*Corresponding Author: Claucia Fernanda Volken de Souza, Universidade do Vale do Taquari - Univates, Av. Avelino Talini, 171, CEP: 95914-014, Lajeado/RS - Brasil, e-mail: claucia@univates.br

Cite as: Herrmann, G., \& Volken de Souza, C. F. (2021). Use of barley malt pomace in the production of fresh sausage. Brazilian Journal of Food Technology, 24, e2020217. https://doi.org/10.1590/1981-6723.21720

\begin{abstract}
The present study aimed to evaluate the effects of barley malt pomace addition on the characteristics of fresh pork sausages over 10 days of storage. Four fresh sausage formulations were elaborated, one with no addition of barley malt pomace (control formulation), and the other three elaborated with $3 \%, 6 \%$, and $9 \%$ of pomace. The sausages were submitted to physicochemical analyses to determine ash, moisture, protein, lipid, carbohydrate, and raw fiber contents, water activity, $\mathrm{pH}$, peroxide indices, and energetic value. Additionally, texture and color technological analysis and sensory analysis were performed. Sausages with $3 \%$ of malt pomace presented a protein content of $17.10 \%$ on the $10^{\text {th }}$ day of storage, and raw fiber content of $2.00 \%$; while in the control formulation these contents were $16.59 \%$ and $0.77 \%$, respectively, with a significant difference $(p \leq 0.05)$ between samples, representing an increase in product nutritional value. In the hardness analysis, the control formulation had a value of $13.99 \mathrm{~N}$ and the formulation with $3 \%$ of pomace of $10.11 \mathrm{~N}$, which shows that sausages with the addition of pomace are not as hard. In the sensory analysis, the control formulation showed about $80 \%$ acceptability in all attributes, the sausage with $3 \%$ of malt pomace had an acceptability index higher than $80 \%$ for the attribute 'global acceptance', the sausage with $6 \%$ of pomace had an index of approximately $70 \%$ and the formulation with $9 \%$ showed acceptability index of approximately $64 \%$ for the attribute 'global acceptance'. The addition of $3 \%$ of malt pomace to the sausage was the best alternative, since it had good acceptance by consumers, and provided an increased nutritional value. Our results show that the use of malt pomace in meat products is a viable alternative that helps to reduce production costs and aids in solving an environmental issue.
\end{abstract}

Keywords: Brewing industry waste; Meat products; Physicochemical analyses; Sensorial analysis; Nutritional value; Fiber content.

\section{Resumo}

O presente trabalho teve o objetivo de avaliar os efeitos da adição do bagaço de malte de cevada nas características de linguiças frescais de carne suína ao longo de 10 dias de armazenamento. Foram elaboradas quatro formulações de linguiça frescal, uma delas sem adição de bagaço de malte (formulação controle) e outras três com 3\%, $6 \%$ e $9 \%$ do bagaço. As linguiças foram submetidas às análises físico-químicas para determinação dos teores de cinzas, 
umidade, proteínas, lipídeos, carboidratos, fibra bruta, atividade de água, $\mathrm{pH}$, índice de peróxidos e valor energético. Também foram realizadas análises tecnológicas de textura e cor e avaliação sensorial. A linguiça com $3 \%$ de bagaço de malte apresentou no $10^{\circ}$ dia de armazenamento teor proteico de $17,10 \%$ e teor de fibra bruta de $2,00 \%$, enquanto na formulação controle esses teores foram de $16,59 \%$ e $0,77 \%$, respectivamente, apresentando diferença significativa $(p \leq 0,05)$ entre as amostras, o que representa um aumento no valor nutricional do produto. Na análise de dureza, a formulação controle apresentou o valor de 13,99 N, e a formulação com 3\% de bagaço, valor de $10,11 \mathrm{~N}$, demonstrando que as linguiças com adição do bagaço ficaram menos rígidas. $\mathrm{Na}$ análise sensorial, a formulação controle apresentou cerca de $80 \%$ de aceitabilidade em todos os atributos; a linguiça com $3 \%$ de bagaço de malte atingiu índice de aceitação global superior a 80\%; a linguiça com 6\% de bagaço obteve índice de aproximadamente $70 \%$; e a formulação com $9 \%$ apresentou índice de aceitação global de aproximadamente $64 \%$. A adição de $3 \%$ de bagaço de malte na linguiça se mostrou a melhor alternativa, pois, além de proporcionar um aumento no valor nutricional do produto, apresentou uma boa aceitabilidade por parte dos consumidores. Os resultados obtidos neste estudo demonstram que o aproveitamento do bagaço de malte em produtos cárneos é uma alternativa viável, que contribui para a redução dos custos de produção e auxilia na solução de um problema ambiental.

Palavras-chave: Resíduo da indústria cervejeira; Produtos cárneos; Análises físico-químicas; Análise sensorial; Valor nutricional; Teor de fibra.

\section{Introduction}

Several agro-industrial residues can be used in the production of fresh sausage, among these residues are those generated by the brewing industry. Beer is one of the most largely consumed drinks worldwide, and it represents an important sector in the Brazilian economy. According to the Brazilian Association of the Brewery Industry (Associação Brasileira da Indústria da Cerveja, 2018), the brewery sector is responsible for $1.6 \%$ of the Brazilian Gross Domestic Product (GDP) and 14\% of the national processing industry. According to data from the Ministry of Agriculture, Livestock, and Supply (Brasil, 2020), 210 new breweries were registered in Brazil in 2018, thus reaching the mark of 899 units throughout the country. As described in the Brazilian legislation (Brasil, 2009), beer is a drink that results from the alcoholic fermentation of the brewing wort, derived from barley malt and drinkable water, due to the action of yeast and the addition of hop. The most abundant ingredient found in beer is water, accounting for over $90 \%$ of the formulation (Rebello, 2009). Aside from water, beer is produced using some types of cereals, among which barley predominates due to its significant starch concentration, which is transformed into maltose and glucose during the malting stage. Hop, which is responsible for the bitter taste and the aroma typical of beer, and yeast, which acts in the fermentation process to produce ethanol, are other essential ingredients in beer production (Morado, 2017; Santos et al., 2013).

Some stages must be observed in beer processing. According to Santos et al. (2013) and Morado (2017), the following stages of the process are essential: malting, beer wort production, initial filtering, boiling, fermentation, maturation, and final processing. This entire process generates some residues, particularly malt pomace, which accounts for $85 \%$ of the residues generated (Mussatto et al., 2006). According to Cordeiro et al. (2012), a total of 14 to $20 \mathrm{~kg}$ of pomace are generated per $100 \mathrm{~L}$ of beer produced. According to the Ministry of Agriculture, Livestock, and Supply (Brasil, 2019), Brazil produces 14 billion liters of beer annually, generating 2 to 3 million tons of malt pomace, which causes a great environmental impact. Almeida et al. (2017) emphasized that this type of residue is rich in fibers, which might account for up to $70 \%$ of its content, and has a significant protein content, varying from $15 \%$ to $30 \%$. Other compounds can be found, such as vitamins and minerals (Aliyu \& Bala, 2011). The manufacture of foods destined for animal nutrition is the major alternative application for malt pomace. However, this residue has been applied in the human diet, used mostly in bakery products, as a partial replacement for flour (Mussatto et al., 2006). The use of malt pomace in the production of meat products is also a good alternative, whether to increase the nutritional value or to replace proteins of animal origin (Nagy et al., 2017).

Pork is another food item consumed in large amounts worldwide, according to data from the United States Department of Agriculture (United States Department of Agriculture, 2019). The major producers and consumers are China, the United States, and the European Union; Brazil comes fourth in the global ranking 
(United States Department of Agriculture, 2019). Meat is a food item with high protein concentration, which might reach up to $22 \%$. However, the component with the highest concentration in water, varying from 65 to $80 \%$. Other components such as lipids, ash, carbohydrates, and vitamins can also be found, yet in lower concentrations (Ordóñez, 2005). Considering that in natura meat is a highly perishable food, the production of sausages is an alternative to increase its shelf life, as well as to provide a higher diversity of consumer products (Oliveira et al., 2005). Fresh sausage is one of the major sausages produced by industries, considering that its elaboration process is relatively simple and it has good acceptance by consumers throughout Brazil (Silva et al., 2013). Due to its characteristics, this type of product cannot be consumed raw and must be stored under refrigeration (Hugo \& Hugo, 2015). Poultry, pork, mixed, and Tuscany sausages are amongst the major fresh products produced (Lemos \& Yamada, 2003).

Brazilian legislation has not established a standard for fiber content in processed meat products such as sausages, which usually exhibit reduced concentrations of this nutrient (Mendes et al., 2014). According to Petersson et al. (2014), increased daily uptake of fibers is important to maintain health and prevent some diseases. New formulations with the addition of plant fibers to meat products have been studied and developed to offer products with functional features, to increase their nutritional value without negatively affecting their sensory and technological characteristics, and seeking to provide consumer well-being (Mendes et al., 2014; Polizer et al., 2015; Oliveira et al., 2013).

Malt pomace, a residue generated in large amounts in the brewery industry, is low cost and has beneficial properties to the organism (Aliyu \& Bala, 2011). Due to its functional characteristics, it helps to reduce cholesterol levels, speeds up intestinal transit, and acts as an antioxidant, thus showing potential for industrial exploitation (Nagy et al., 2017; Mussatto et al., 2006; Almeida et al., 2017). The addition of this ingredient in the production of kebab (França et al., 2016), smoked sausage (Nagy et al., 2017), and Frankfurters (Özvural et al., 2009) has shown good results, providing increased nutritional value to the products.

Therefore, the present study aimed to use beer malt pomace, a beer processing by-product, in the manufacture of pork fresh sausage, hence adding value to this by-product. The addition of this ingredient was intended for increased end-product yield and reduced production costs. Four fresh sausage formulations were elaborated, including one control formulation, without the addition of malt pomace, and three other formulations, with different concentrations of this ingredient. All sausages were evaluated regarding their physicochemical, technological, and sensory characteristics throughout 10 days of storage under refrigeration at $5{ }^{\circ} \mathrm{C}$. In addition, the dry malt pomace used to elaborate sausages was analyzed regarding its granulometry, coloration, and physicochemical characteristics.

\section{Material and methods}

\subsection{Obtaining the raw material}

Barley malt pomace was obtained from a brewery in Taquari Valley - RS, derived from the production of a Pilsen beer. Pomace was submitted to a drying process using a tray dryer (Pardal PEG60, Petrópolis, RJ, Brazil), at $50{ }^{\circ} \mathrm{C}$ for $15 \mathrm{~h}$, to reach lower moisture than $10 \%$. Subsequently, it was grounded using a food processor (Philips RI7630, Varginha, MG, Brazil), to reduce particle size. After grounding, malt pomace was submitted to a granulometric analysis using a sieve shaker (Bertel 50BA, Caieiras, SP, Brazil). Sieves with aperture sizes of 149, 297, 595, 1190, 2000, and $4000 \mu \mathrm{m}$ were used to perform this analysis, corresponding to Tyler series $100,48,28,14,9$, and 5, respectively, with a plate with no holes at the base. Sieves were placed on the equipment in increasing aperture order, from the base to the top, and the shaking process took place for $10 \mathrm{~min}$ with a vibration intensity of $80 \%$. Additionally, color analysis was performed using a colorimeter (Konica Minolta CM-5, Hino-shi, Tokyo, Japan) and physicochemical analyses of ash, moisture, proteins, lipids, carbohydrates, water activity, and energetic value were performed according to the methodologies described by Adolfo Lutz Institute (Instituto Adolfo Lutz, 2008) and the raw fiber content was performed according to the methodology described by the Association of Official Analytical Chemists (Association of Official Analytical Chemists, 2012).

The other ingredients required for the production of fresh sausage were obtained at the local market, in the city of Lajeado - RS. 


\subsection{Sausage formulations}

Four sausage formulations were elaborated, one being the control formulation (CS formulation) produced with ingredients that are commonly used in the production of fresh sausages, namely pork, pork lard, water, sodium chloride, curing salt, powder garlic, and powder nutmeg. Formulations S3, S6, and S9 were elaborated with the addition of $3 \%, 6 \%$, and $9 \%$ of malt pomace, respectively, to replace pork. The other ingredients were used at the same concentrations as those of the CS Formulation. Table 1 describes all ingredients that were used in the elaboration of sausages, as well as their corresponding percentages.

Table 1. Ingredients used in sausage formulations.

\begin{tabular}{ccccc}
\hline \multirow{2}{*}{ Ingredients } & \multicolumn{3}{c}{ Formulations } \\
\cline { 2 - 5 } & CS & S3 & S6 & S9 \\
\hline Pork (\%) & 77.49 & 74.49 & 71.49 & 68.49 \\
\hline Pork lard (\%) & 10.00 & 10.00 & 10.00 & 10.00 \\
\hline Water (\%) & 10.00 & 10.00 & 10.00 & 10.00 \\
\hline Sodium chloride (\%) & 2.00 & 2.00 & 2.00 & 0.015 \\
\hline Curing salt (\%) & 0.015 & 0.015 & 0.015 & 0.25 \\
\hline Powder garlic (\%) & 0.25 & 0.25 & 0.25 & 0.25 \\
\hline Powder nutmeg (\%) & 0.25 & 0.25 & 0.25 & 9.00 \\
\hline Malt pomace (\%) & - & 3.00 & 6.00 & \\
\hline
\end{tabular}

CS: Control formulation; S3: formulation with $3 \%$ malt pomace; S6: formulation with $6 \%$ malt pomace; S9: formulation with $9 \%$ malt pomace.

In all fresh sausage formulations, pork and lard underwent the grinding stage through a meat grinder (G. Paniz MCR 10, Caxias do Sul, RS, Brazil) with an 8-mm disc, followed by addition of water, sodium chloride, curing salt, powder garlic, and powder nutmeg. Previously prepared malt pomace was also added to formulations S3, S6, and S9. All ingredients were mixed manually, which allowed for the formation of a smooth mixture. This mixture was then embedded in a natural pork casing, with an approximate diameter of $25 \mathrm{~mm}$ with the help of a manual vacuum filler.

Samples were packaged in transparent polyethylene bags, stored under refrigeration at $5{ }^{\circ} \mathrm{C}$, and had their physicochemical characteristics analyzed, after the $1^{\text {st }}$ and $10^{\text {th }}$ days of storage, and their technological characteristics were analyzed after the $10^{\text {th }}$ day of storage. This period was defined considering the shelf life of the commercial fresh sausage. Sensory analysis was performed on the $3^{\text {rd }}$ day of product storage, to evaluate the sensory characteristics of the fresh sausage recently elaborated.

\subsection{Determination of physicochemical characteristics}

The following were determined in the sausages: ash, moisture, lipid, protein, carbohydrate, and raw fiber contents, as well as energetic value and water activity. Additionally, $\mathrm{pH}$ and oxidative rancidity were measured. The raw fiber content was performed according to the methodology described by the Association of Official Analytical Chemists (Association of Official Analytical Chemists, 2012) and the other analyses were performed according to the methodologies described by Adolfo Lutz Institute (Instituto Adolfo Lutz, 2008).

Ashes were determined by incinerating the product in a muffle (Quimis Q-318M, Diadema, SP, Brazil) at $550{ }^{\circ} \mathrm{C}$, according to the method of Adolfo Lutz Institute (Instituto Adolfo Lutz, 2008). To determine moisture, the sample was heated in an oven (Ethiktechnology 404-3D, Vargem Grande Paulista, SP, Brazil) at $105^{\circ} \mathrm{C}$ and was subsequently cooled in a desiccator until the weight was constant. Lipids were determined based on the direct extraction method using solvents, in a Soxhlet extractor. The Kjeldahl method was used to analyze protein content; in this method, the total nitrogen content is determined, and then, converted into 
raw protein using the factor 6.25. To determine the $\mathrm{pH}$ of samples, a bench potentiometer (Digimed DM-22, São Paulo, SP, Brazil) was used. The rancidity degree of lipids present in sausages was determined using peroxide index. For this analysis, samples were treated with an acetic acid-chloroform solution (3:2), with addition of saturated potassium iodide and starch-indicator solution. Titration was performed with sodium thiosulphate (Instituto Adolfo Lutz, 2008). Carbohydrate content was determined by calculating the difference between $100 \mathrm{~g}$ of sample and the sum of ash, moisture, protein, and lipid values. Energetic value in $100 \mathrm{~g}$ of sausage was calculated by the sum of protein, lipid, and carbohydrate concentrations, multiplied by their corresponding conversion factors $\left(4 \mathrm{kcal} \mathrm{g}^{-1}, 9 \mathrm{kcal} \mathrm{g}^{-1}\right.$, and $\left.4 \mathrm{kcal} \mathrm{g}^{-1}\right)$ (Brasil, 2003). To analyze the raw fiber content, samples were treated with $1.25 \%$ sulfuric acid $(\mathrm{v} / \mathrm{v})$, and then, with $1.25 \%$ sodium hydroxide $(\mathrm{v} / \mathrm{v})$. After that, they were heated in a furnace at $105{ }^{\circ} \mathrm{C}$, cooled and calcinated in a muffle at $550^{\circ} \mathrm{C}$, according to the AOAC method (Association of Official Analytical Chemists, 2012). Water activity was determined using a water activity analyzer (Aqualab Lite, Rio de Janeiro, RJ, Brazil).

\subsection{Determination of technological characteristics}

The texture characteristics of raw sausage samples were evaluated using a texture analyzer (Brookfield CT3, Middleboro, MA, USA). The method used was Texture Profile Analysis (TPA), in which two compression and decompression cycles were performed. The $25-\mathrm{mm}$ samples were compressed to $50 \%$ of their initial thickness, with a test speed of $2 \mathrm{~mm} \mathrm{~s}^{-1}$, TA25/1000 probe, and $10 \mathrm{~kg}$ loading cell, according to the method adapted from Sisik et al. (2012). Parameters 'hardness', 'cohesiveness', 'elasticity', 'gumminess', and 'chewiness' were analyzed with the help of Texture Pro CT V 1.8.

Malt pomace and sausage color were analyzed using a colorimeter (Konica Minolta CM-5, Hino-shi, Tokyo, Japan), with which the parameters ' $\mathrm{L}^{*}$ ', 'a*', and 'b*' were evaluated. $\mathrm{L}^{*}$ value is related to luminosity and indicates color variation from black to white, $a^{*}$ represents the level of red coloration in the sample, and 'b*' indicates the level of yellow coloration (Choi et al., 2015).

\subsection{Determination of sensorial characteristics}

Sensory analysis was performed at the Laboratory of Sensory Analysis of the Taquari Valley University - Univates by a group of 60 untrained tasters, recruited from Univates students and staff; 24 were men and 26 were women aged between 18 and 50, who analyzed the attributes 'appearance', 'color', 'flavor', 'scent', 'texture', and 'global acceptance'. The untrained tasters, who participated in the sensory analysis, like fresh sausage and consume this product regularly. These characteristics have been asked to all individuals invited for the sensory analysis, before they had performed the sensory analysis of the fresh sausages. The samples were previously baked in a combi oven (Tedesco TC-6G, Caxias do Sul, RS, Brazil) at $180^{\circ} \mathrm{C}$ for $60 \mathrm{~min}$ at the Dietetic Technique Laboratory of the Taquari Valley University - Univates. Sensory analysis was performed in individual cabinets with white light and at room temperature, and samples were placed on disposable plastic plates. The samples were divided in standardized portions of approximately $10 \mathrm{~g}$ and identified with three random digits; they were then provided to tasters for sensory evaluation. Together with the samples, cups with mineral water at room temperature (for tasters to cleanse their palate) and an assessment form were offered. Sensory analysis was performed using the acceptance test with a structured nine-point hedonistic scale, where score 1 refers to the term "disliked it immensely" and 9 means "liked it immensely" (Instituto Adolfo Lutz, 2008). The acceptability index of the samples was calculated by dividing the mean value of results by the highest score possible in each attribute, multiplied by 100 . Prior to performing the analyses, the present study was submitted to the Research Ethics Committee (COEP) of the University for evaluation, and it was approved under report number 3.448.411 and CAAE: 15125819.2.0000.5310. 


\subsection{Statistical data analysis}

Three batches of each sausage formulation were elaborated and were analyzed in duplicates. The results of physico-chemical, technological, and sensory analyses of the different sausage formulations were statistically evaluated using an analysis of variance (ANOVA) and the significance of the models was evaluated using the F-test. In the samples that had significant difference, mean values were compared using Tukey's test, with a confidence level of $95 \%(p \leq 0.05)$. To check if there was significant difference between samples from the $1^{\text {st }}$ and $10^{\text {th }}$ days of storage, a Student's t-test was performed for each characteristic evaluated, also adopting the confidence level of $95 \%(p \leq 0.05)$. Statistica 13.1 (Dell Statistica ${ }^{\circledR}$, US) was used to statistically analyze results.

\section{Results and discussion}

\subsection{Characterization of dry malt pomace}

After grinding, malt pomace particles had a mean diameter of $951 \mu \mathrm{m}$, and color analysis indicated values of 52.99, 5.54, and 20.91 for parameters $\mathrm{L}^{*}$, $\mathrm{a}^{*}$, and b*, respectively. Results of the physicochemical analyses of malt pomace are shown in Table 2 .

Table 2. Results of physicochemical analyses of malt pomace.

\begin{tabular}{cc}
\hline Component & Dry malt pomace \\
\hline Ash (\%) & $3.77 \pm 0.01$ \\
\hline Moist (\%) & $7.78 \pm 0.23$ \\
\hline Proteins (\%) & $19.72 \pm 0.29$ \\
\hline Lipids (\%) & $2.05 \pm 0.19$ \\
\hline Carbohydrates (\%) & $67.09 \pm 0.24$ \\
\hline Raw fiber (\%) & $19.87 \pm 0.60$ \\
\hline Water activity & $0.537 \pm 0.001$ \\
\hline Energetic value (kcal $\left.100 \mathrm{~g}^{-1}\right)$ & $363.88 \pm 0.88$ \\
\hline
\end{tabular}

Results expressed as mean value \pm standard deviation.

Results in Table 2 show that dry malt pomace exhibits high protein, carbohydrate, and raw fiber contents. Additionally, it has low moisture, which favors conservation and helps to decrease volume (Aliyu \& Bala, 2011). The high energetic value of $363.88 \mathrm{kcal}^{100 \mathrm{~g}^{-1}}$ is related to the high concentration of proteins and carbohydrates. Nagy et al. (2017) found $3.80 \%$ ash content, $7.90 \%$ moist content, $13.50 \%$ proteins, $4.80 \%$ lipids, and $70 \%$ carbohydrates in the malt pomace used to manufacture smoked sausage. Özvural et al. (2009) analyzed grounded malt pomace at different granulometry values to use in Frankfurters and they observed protein content between 23 and $31 \%$, moisture content between $6.70 \%$ and $7.60 \%$, and ash content between $3.57 \%$ and $3.76 \%$. The raw fiber concentration observed in the present study, $19.87 \%$, is different from the findings by Madubuike \& Okolo (2016), who characterized malt pomace and found the value of $10.44 \%$. According to Mussatto et al. (2006), differences in values obtained in the characterization of malt pomace might be related to barley variety, type of processing, and equipment used. Regarding water activity, the value found is considered to be intermediate, which enables to control water content and the microbiological safety of foods (Damodaran \& Parkin, 2019).

\subsection{Physicochemical characteristics of sausages}

Table 3 shows the results of physicochemical analyses performed with sausages on the $1^{\text {st }}$ day of storage and after the $10^{\text {th }}$ day of storage, as well as the energetic value of formulations. Ash content in the samples varied from $2.46 \%$ to $2.96 \%$, and there was no significant difference between them. Samples also showed no 
difference in ash content between the $1^{\text {st }}$ and the $10^{\text {th }}$ days of storage, with values varying from $2.87 \%$ to $3.05 \%$. Ash results in the present study are like those observed by Borrajo et al. (2016), who found values between $3.2 \%$ and $3.4 \%$ in a wheat fiber-enriched sausage.

Moisture content in the CS formulation was $64.55 \%$ on the $1^{\text {st }}$ day of storage, while samples S3, S6, and S9 had $60.11 \%, 59.22 \%$, and $58.68 \%$, respectively, thus indicating a significant difference between them $(p \leq 0.05)$. The decrease in moisture content in the sausages samples is probably due to the replacement of meat (higher moisture content) by the malt pomace (lower moisture content) in the sausage's formulations. Nagy et al. (2017) also observed reduced moisture content in a smoked sausage with addition of malt pomace; moisture content was $66.30 \%$ in the control formulation and $53.90 \%$ in the formulation with $6 \%$ of pomace. Choi et al. (2015) showed that addition of rice fiber to a sausage also caused moisture to decrease. After 10 days of storage, all sausage formulations had increased moisture, with significant difference $(p \leq 0.05)$ compared to the $1^{\text {st }}$ day, and this might be explained by the loss of water in pork after a few days of storage (Ramos \& Gomide, 2007). Addition of malt pomace to sausages also helped remove free water from the medium, thus causing water activity to decrease in the product. However, the high value found might favor food degradation and change its quality (Damodaran \& Parkin, 2019).

Table 3. Results of physicochemical analyses and analysis of energetic value of sausages with malt pomace.

\begin{tabular}{|c|c|c|c|c|c|}
\hline \multirow{2}{*}{ Component } & \multirow{2}{*}{ Storage period } & \multicolumn{4}{|c|}{ Formulations } \\
\hline & & CS & $\mathbf{S 3}$ & S6 & S9 \\
\hline \multirow{2}{*}{ Ash (\%) } & 1 day & $2.46 \pm 0.43^{\mathrm{aA}}$ & $2.61 \pm 0.21^{\mathrm{aA}}$ & $2.78 \pm 0.13^{\mathrm{aA}}$ & $2.96 \pm 0.10^{\mathrm{aA}}$ \\
\hline & 10 days & $2.87 \pm 0.08^{\mathrm{aA}}$ & $2.91 \pm 0.19^{\mathrm{aA}}$ & $2.90 \pm 0.16^{\mathrm{aA}}$ & $3.05 \pm 0.14^{\mathrm{aA}}$ \\
\hline \multirow{2}{*}{ Moist (\%) } & 1 day & $64.55 \pm 0.48^{\mathrm{aB}}$ & $60.11 \pm 0.61^{\mathrm{bB}}$ & $59.22 \pm 0.46^{\mathrm{bcB}}$ & $58.68 \pm 0.89^{\mathrm{cB}}$ \\
\hline & 10 days & $67.35 \pm 0.83^{\mathrm{aA}}$ & $64.55 \pm 1.05^{\mathrm{bA}}$ & $63.42 \pm 0.53^{\mathrm{bcA}}$ & $61.11 \pm 0.67^{\mathrm{cA}}$ \\
\hline \multirow{2}{*}{ Proteins (\%) } & 1 day & $15.61 \pm 0.48^{\mathrm{bA}}$ & $16.67 \pm 0.48^{\mathrm{abA}}$ & $16.73 \pm 0.60^{\mathrm{abA}}$ & $17.21 \pm 0.41^{\mathrm{aA}}$ \\
\hline & 10 days & $16.59 \pm 0.46^{\mathrm{bA}}$ & $17.10 \pm 0.46^{\mathrm{abA}}$ & $17.44 \pm 0.27^{\mathrm{abA}}$ & $18.03 \pm 0.44^{\mathrm{aA}}$ \\
\hline \multirow{2}{*}{ Lipids (\%) } & 1 day & $10.31 \pm 0.43^{\mathrm{aA}}$ & $10.46 \pm 0.40^{\mathrm{aA}}$ & $10.99 \pm 0.9^{\mathrm{aA}}$ & $10.95 \pm 0.64^{\mathrm{aA}}$ \\
\hline & 10 days & $9.72 \pm 0.09^{\mathrm{aA}}$ & $9.91 \pm 0.46^{\mathrm{aA}}$ & $10.40 \pm 0.34^{\mathrm{aA}}$ & $10.42 \pm 0.45^{\mathrm{aA}}$ \\
\hline \multirow{2}{*}{ Carbohydrates (\%) } & 1 day & $7.08 \pm 0.29^{\mathrm{bA}}$ & $10.15 \pm 1.05^{\mathrm{aA}}$ & $10.28 \pm 0.69^{\mathrm{aA}}$ & $10.31 \pm 1.05^{\mathrm{aA}}$ \\
\hline & 10 days & $3.48 \pm 0.63 \mathrm{bB} \mathrm{B}^{\mathrm{bB}}$ & $5.54 \pm 0.85^{\mathrm{abB}}$ & $5.83 \pm 0.34^{\mathrm{aB}}$ & $7.38 \pm 0.83^{\mathrm{aB}}$ \\
\hline \multirow{2}{*}{ Water activity } & 1 day & $0.907 \pm 0.003^{\mathrm{aA}}$ & $0.904 \pm 0.002^{\mathrm{aA}}$ & $0.898 \pm 0.003^{\mathrm{bA}}$ & $0.895 \pm 0.001^{\mathrm{bA}}$ \\
\hline & 10 days & $0.909 \pm 0.002^{\mathrm{aA}}$ & $0.906 \pm 0.001^{\mathrm{aA}}$ & $0.900 \pm 0.002^{\mathrm{bA}}$ & $0.898 \pm 0.001^{\mathrm{bA}}$ \\
\hline \multirow{2}{*}{$\mathrm{pH}$} & 1 day & $5.98 \pm 0.02^{\mathrm{cA}}$ & $6.04 \pm 0.02^{\mathrm{cA}}$ & $6.19 \pm 0.06^{\mathrm{bA}}$ & $6.31 \pm 0.03^{\mathrm{aA}}$ \\
\hline & 10 days & $5.93 \pm 0.03^{\mathrm{bA}}$ & $5.99 \pm 0.02^{\mathrm{bA}}$ & $6.16 \pm 0.04^{\mathrm{aA}}$ & $6.23 \pm 0.04^{\mathrm{aB}}$ \\
\hline \multirow{2}{*}{ PI (meq kg-1) } & 1 day & $0.76 \pm 0.11^{\mathrm{aB}}$ & $0.82 \pm 0.15^{\mathrm{aB}}$ & $0.96 \pm 0.06^{\mathrm{aB}}$ & $1.02 \pm 0.34^{\mathrm{aB}}$ \\
\hline & 10 days & $1.45 \pm 0.06^{\mathrm{bA}}$ & $1.65 \pm 0.11^{\mathrm{abA}}$ & $1.71 \pm 0.15^{\mathrm{aA}}$ & $1.78 \pm 0.17^{\mathrm{aA}}$ \\
\hline \multirow{2}{*}{$\begin{array}{l}\text { Energetic value } \\
\left(\text { kcal } 100 \mathrm{~g}^{-1}\right)\end{array}$} & 1 day & $183.53 \pm 4.89^{\mathrm{bA}}$ & $201.40 \pm 4.30^{\mathrm{aA}}$ & $206.94 \pm 3.29^{\mathrm{aA}}$ & $208.62 \pm 4.14^{\mathrm{aA}}$ \\
\hline & 10 days & $167.74 \pm 3.24^{\mathrm{bB}}$ & $179.74 \pm 7.14^{\mathrm{bB}}$ & $186.72 \pm 2.19^{\mathrm{abB}}$ & $195.48 \pm 3.72^{\mathrm{aB}}$ \\
\hline Raw fiber (\%) & 10 days & $0.77 \pm 0.05^{\mathrm{d}}$ & $2.00 \pm 0.10^{\mathrm{c}}$ & $2.46 \pm 0.09^{\mathrm{b}}$ & $3.10 \pm 0.20^{\mathrm{a}}$ \\
\hline
\end{tabular}

Results expressed as mean value \pm standard deviation. CS: Control formulation; S3: formulation with 3\% malt pomace; S6: formulation with $6 \%$ malt pomace; S9: formulation with 9\% malt pomace; PI: peroxide index. Different lowercase letters in the same row represent significant difference between samples using Tukey's test $(p \leq 0.05)$. Different uppercase letters in the same column for each characteristic represent a significant difference between formulations throughout storage period, using Student's t-test $(p \leq 0.05)$. 
Regarding protein content, formulation S9 had $17.21 \%$ while formulation CS had $15.61 \%$, indicating that there was a significant difference $(p \leq 0.05)$. The other formulations also had higher values that the CS; however, differences were not significant. These results show that the addition of malt pomace provided increased protein value in the sausage. Protein content increased in all samples on the $10^{\text {th }}$ day of storage, varying from $16.59 \%$ to $18.03 \%$. However, the difference from the $1^{\text {st }}$ day was not significant. Increased protein value was also observed by Nagy et al. (2017), who added malt pomace to smoked sausage. The authors observed that the control formulation had a value of $11.60 \%$ of protein, while the formulation with addition of malt pomace obtained a value of $12.90 \%$. The addition of wine-processing by-product meal to salami also provided increased protein content, according to a study by Mendes et al. (2014).

Lipid concentration varied from 10.31 to $10.95 \%$ amongst the different sausage formulations, with no significant differences. Since malt pomace has a low lipid concentration, its addition to the sausage did not affect this parameter. From the $1^{\text {st }}$ to the $10^{\text {th }}$ day of storage, there was a reduction between $0.53 \%$ and $0.59 \%$ in the lipid content of sausages, although this difference was not significant, either. Borrajo et al. (2016) did not observe difference in lipid content of sausages with addition of wheat fiber, either. These results are different from the values found by Özvural et al. (2009), who analyzed Frankfurters with addition of malt pomace, and found a lipid content of $15.92 \%$, while the control formulation had a value of $18.05 \%$.

Sausage samples had carbohydrate concentrations of $7.08 \%$ and $10.31 \%$ on the $1^{\text {st }}$ day of storage, and CS formulation statistically differed from the others $(p \leq 0.05)$. The high concentration of this nutrient in malt pomace explains this increase. These values decreased on the $10^{\text {th }}$ day of storage, showing difference compared to the $1^{\text {st }}$ day, due to increased moisture and protein content. Increased carbohydrate content was also observed by Choi et al. (2015) and Nagy et al. (2017), who added rice fiber in sausages and malt pomace in smoked sausage, respectively. Regarding the energetic value of samples, results varied from 183.53 to

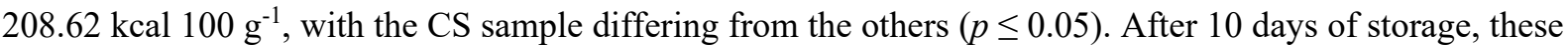

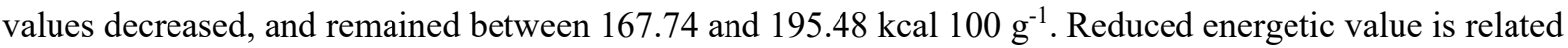
to the decrease in lipid and carbohydrate contents throughout the storage period.

The $\mathrm{pH}$ value of the CS sample on the $1^{\text {st }}$ day of storage was 5.98 and it increased with the addition of malt pomace, reaching 6.19 in S6 and 6.31 in S9, indicating that these two samples statistically differ from $\mathrm{CS}(p \leq 0.05)$. According to Bezerra et al. (2012) the $\mathrm{pH}$ of meat products usually lies in the range between 5.4 and 6.2. After 10 days of storage, the $\mathrm{pH}$ of all sausages decreased, remaining between 5.93 and 6.23. These values are like the results obtained by Marti-Quijal et al. (2019), who added different types of plant protein to pork sausages and obtained $\mathrm{pH}$ values between 5.93 and 6.15 .

Lipid oxidation is one of the major factors that cause meet degradation and is an important quality indicator (Gois et al., 2017). Results in Table 3 show peroxide index values between 0.76 and $1.02 \mathrm{meq} \mathrm{kg} \mathrm{after}^{-1}$ the $1^{\text {st }}$ day of storage, with significant difference between CS and the other samples $(p \leq 0.05)$. After a storage period of 10 days, the peroxide index increased in all samples and values ranged from 1.45 to 1.78 meq $\mathrm{kg}^{-1}$, representing a significant difference $(p \leq 0.05)$ compared to the $1^{\text {st }}$ day. Despite this increase, values were lower than those observed by Qin et al. (2013), who analyzed fresh ground pork meat, which had a peroxide index of 5.51 meq kg-1 after 3 days of storage. Analyses performed by Bazargani-Gilani et al. (2015) with chicken breast meet also indicated increased peroxide index from the $1^{\text {st }}$ to the $10^{\text {th }}$ day of storage. According to the authors, peroxide formation is faster on the first days of storage, and after that, the product is degraded, forming secondary oxidation products. According to the Food and Agriculture Organization (Food and Agriculture Organization, 1995), in fats of animal origin the peroxide index of up to $5 \mathrm{meq} \mathrm{kg}^{-1}$ is acceptable.

In raw fiber analysis, samples CS, S3, S6, and S9 had a significant difference $(p \leq 0.05)$ and the mean values found were $0.77 \%, 2.00 \%, 2.46 \%$, and $3.10 \%$, respectively. Increased fiber content was expected due to the addition of malt pomace, which has a high concentration of this nutrient in its composition. The presence of fibers in the sausages resulted in a more nutritious product, which provides several benefits to health. Increased fiber content was also observed by Özvural et al. (2009), with the addition of malt pomace 
to Frankfurters. They observed that fiber content reached $3.89 \%$ in sausage with $5 \%$ of pomace, ground at a finer granulometry. Pintado et al. (2018) added chia and oatmeal to fresh sausages and observed increased fiber content in both formulations.

\subsection{Technological characteristics of sausages}

Results of the texture analyses of the different sausage formulations are shown in Table 4.

Table 4. Results of texture analyses of sausages with malt pomace.

\begin{tabular}{ccccc}
\hline \multirow{2}{*}{ Parameter } & \multicolumn{4}{c}{ Formulations } \\
\cline { 2 - 5 } & $\mathbf{C S}$ & $\mathbf{S 3}$ & $\mathbf{S 6}$ & S9 \\
\hline Hardness (N) & $13.99 \pm 1.98^{\mathrm{a}}$ & $10.11 \pm 1.66^{\mathrm{ab}}$ & $5.92 \pm 0.83^{\mathrm{b}}$ & $5.83 \pm 0.58^{\mathrm{b}}$ \\
\hline Cohesiveness & $0.37 \pm 0.04^{\mathrm{a}}$ & $0.30 \pm 0.04^{\mathrm{a}}$ & $0.39 \pm 0.05^{\mathrm{a}}$ & $0.38 \pm 0.01^{\mathrm{a}}$ \\
\hline Gumminess (N) & $5.76 \pm 0.43^{\mathrm{a}}$ & $3.00 \pm 0.58^{\mathrm{b}}$ & $2.30 \pm 0.46^{\mathrm{b}}$ & $2.23 \pm 0.28^{\mathrm{b}}$ \\
\hline Elasticity & $0.93 \pm 0.02^{\mathrm{a}}$ & $0.91 \pm 0.03^{\mathrm{a}}$ & $0.88 \pm 0.02^{\mathrm{a}}$ & $0.86 \pm 0.01^{\mathrm{ab}}$ \\
\hline Chewiness (N) & $5.37 \pm 0.32^{\mathrm{a}}$ & $2.76 \pm 0.62^{\mathrm{b}}$ & $2.03 \pm 0.44^{\mathrm{b}}$ & $1.93 \pm 0.27^{\mathrm{b}}$ \\
\hline
\end{tabular}

Results expressed as mean value \pm standard deviation. CS: Control formulation; S3: formulation with 3\% malt pomace; S6: formulation with $6 \%$ malt pomace; S9: formulation with $9 \%$ malt pomace. Different lowercase letters in the same row represent significant difference between samples using Tukey's test $(p \leq 0.05)$

Results in Table 4 indicate a significant difference $(p \leq 0.05)$ in hardness between CS formulation and formulations S6 and S9. It is possible to observe that there was a reduction from $13.99 \mathrm{~N}$ in the control formulation (CS) to $5.83 \mathrm{~N}$ in the formulation with $9 \%$ of malt pomace (S9). Özvural et al. (2009) and Sisik et al. (2012) also observed reduction in sausage hardness, adding malt pomace and broccolis fiber, respectively. According to Özvural et al. (2009), the addition of plant fiber might have provided a lower hardness to the products. Choi et al. (2015) did not obtain the same results, as they observed increased hardness in a sausage with addition of rice fiber. However, it is worth noting that there was also increased addition of fat proportion in this study, which might have affected the result. Cohesiveness values are similar among all samples, while sample $\mathrm{S} 9$ had a significant difference $(p \leq 0.05)$ in the elasticity analysis. Chewiness was also higher in the CS formulation, as this parameter is related with hardness.

Table 5 shows the results of color analyses performed with sausages with addition of malt pomace. Data shows that there was a significant difference $(p \leq 0.05)$ in coloration among samples regarding the parameter 'L*', which is related to luminosity.

Table 5. Results of color analyses of sausages with malt pomace.

\begin{tabular}{ccccc}
\hline \multirow{2}{*}{ Parameter } & \multicolumn{4}{c}{ Formulations } \\
\cline { 2 - 5 } & CS & S3 & S6 & S9 \\
\hline $\mathrm{L}^{*}$ & $60.54 \pm 1.38^{\mathrm{a}}$ & $53.76 \pm 0.20^{\mathrm{b}}$ & $50.66 \pm 0.42^{\mathrm{c}}$ & $48.65 \pm 0.43^{\mathrm{c}}$ \\
\hline $\mathrm{a}^{*}$ & $5.69 \pm 0.046 \mathrm{a}^{\mathrm{b}}$ & $6.51 \pm 0.40^{\mathrm{a}}$ & $5.17 \pm 0.18^{\mathrm{b}}$ & $5.20 \pm 0.24^{\mathrm{b}}$ \\
\hline $\mathrm{b}^{*}$ & $14.59 \pm 0.25^{\mathrm{a}}$ & $14.02 \pm 0.15^{\mathrm{b}}$ & $13.94 \pm 0.21^{\mathrm{b}}$ & $14.11 \pm 0.09^{\mathrm{b}}$ \\
\hline
\end{tabular}

Results expressed as mean value \pm standard deviation. CS: Control formulation; S3: formulation with 3\% malt pomace; S6: formulation with $6 \%$ malt pomace; S9: formulation with $9 \%$ malt pomace. Different lowercase letters in the same row represent significant difference between samples using Tukey's test $(p \leq 0.05)$

It is clear that the more malt pomace was added to the formulations, the lower was the luminosity, i.e., the darker the sausage mass was. This characteristic is not expected in pork sausage, but it can be explained by 
the presence of malt pomace, which has a dark coloration (Mussatto et al., 2006). Regarding the parameter ' ${ }^{*}$ ', which is related to the intensity of red coloration, only sample S3 had a significant difference $(p \leq 0.05)$ compared to formulations S6 and S9. CS sample had the highest ' $b$ *' value, which indicates intensity of yellow coloration, showing that there is a difference compared to the other formulations. According to Borrajo et al. (2016), the addition of wheat fiber to sausages also caused reduced $\mathrm{L}^{*}$ value. In the study mentioned, $a^{*}$ and $b^{*}$ did not have differences among formulations. Reduced $\mathrm{L}^{*}$ value in sausages with addition of malt pomace was also addressed by Özvural et al. (2009), who also observed reduced a* value and increased $b *$ value.

\subsection{Sensory characteristics of sausages}

Sensory analysis was performed using the 9-point hedonic scale and results are shown in Table 6. Despite having the highest hardness, the CS formulation was observed to obtain the best scores in the instrumental texture analysis (Table 4), above 7 in all attributes, and was differentiated from formulations S6 and S9 $(p \leq 0.05)$. Formulation S3 got scores between 6.85 and 7.42 and did not have a significant difference compared the CS formulation in all attributes evaluated, which indicates that the addition of $3 \%$ of sausage by-product was well accepted by the tasters. The characteristics of formulation S9 were differentiated due to the higher addition of malt pomace, which caused the scores attributed by tasters to be lower than those observed in the other formulations. However, this formulation had the highest nutritional value, according to results in Table 3.

Table 6. Results of sensory analyses of sausages with malt pomace.

\begin{tabular}{ccccc}
\hline \multirow{2}{*}{ Attribute } & \multicolumn{4}{c}{ Formulations } \\
\cline { 2 - 5 } & $\mathbf{C S}$ & $\mathbf{S 3}$ & $\mathbf{S 6}$ & $\mathbf{S 9}$ \\
\hline Appearance & $7.23 \pm 1.42^{\mathrm{a}}$ & $6.87 \pm 1.53^{\mathrm{a}}$ & $5.98 \pm 1.42^{\mathrm{b}}$ & $5.67 \pm 1.56^{\mathrm{b}}$ \\
\hline Color & $7.30 \pm 1.44^{\mathrm{a}}$ & $6.85 \pm 1.53^{\mathrm{a}}$ & $6.05 \pm 1.53^{\mathrm{b}}$ & $5.65 \pm 1.60^{\mathrm{b}}$ \\
\hline Flavor & $7.35 \pm 1.56^{\mathrm{a}}$ & $7.23 \pm 1.47^{\mathrm{a}}$ & $6.20 \pm 1.84^{\mathrm{b}}$ & $5.83 \pm 1.99^{\mathrm{b}}$ \\
\hline Scent & $7.48 \pm 1.21^{\mathrm{a}}$ & $7.42 \pm 1.28^{\mathrm{a}}$ & $6.60 \pm 1.63^{\mathrm{b}}$ & $6.43 \pm 1.58^{\mathrm{b}}$ \\
\hline Texture & $7.13 \pm 1.56^{\mathrm{a}}$ & $6.95 \pm 1.38^{\mathrm{a}}$ & $6.02 \pm 1.75^{\mathrm{b}}$ & $5.80 \pm 1.82^{\mathrm{b}}$ \\
\hline Global Acceptance & $7.27 \pm 1.41^{\mathrm{a}}$ & $7.22 \pm 1.26^{\mathrm{a}}$ & $6.23 \pm 1.57^{\mathrm{b}}$ & $5.75 \pm 1.79^{\mathrm{b}}$ \\
\hline
\end{tabular}

Results expressed as mean value \pm standard deviation. Acceptance test with a structured nine-point hedonistic scale, where score 1 refers to the term "disliked it immensely" and 9 means "liked it immensely". CS: Control formulation; S3: formulation with 3\% malt pomace; S6: formulation with $6 \%$ malt pomace; S9: formulation with $9 \%$ malt pomace. Different lowercase letters in the same row represent significant difference between samples using Tukey's test $(p \leq 0.05)$.

Nagy et al. (2017) produced a smoked sausage with addition of $6 \%$ of malt pomace, and in the texture analysis of the different attributes, they obtained results of 6.9 and 7.9. Özvural et al. (2009) added malt pomace to Frankfurters and also obtained results close to 7.0 in all sensory attributes evaluated.

Regarding the acceptance index, the CS sample had approximately $80 \%$ in all attributes, and the global acceptance index was $80.74 \%$. Samples S3, S6, and S9 had global acceptance index of $80.19 \%, 69.26 \%$, and $63.89 \%$, respectively. According to Dutcoski (2015), for a product to be considered accepted regarding its sensory characteristics, the acceptability index must be approximately $70 \%$. Therefore, the sensory evaluation of sausages showed that formulations with $3 \%$ and $6 \%$ of malt pomace were well accepted by tasters and had potential for commercialization. 


\section{Conclusion}

The results of the present study showed that malt pomace is a viable alternative to be used in meat products. Sausage formulation formulation with addition of $3 \%$ of malt pomace had protein content of $17.10 \%$ and raw fiber content of $2.00 \%$, which are higher values than those of the control formulation, thus representing an increase in product nutritional value. Regarding hardness, formulations with addition of pomace were not as hard as the formulation without pomace. In the sensory analysis, the sausage with $3 \%$ of malt pomace reached a global acceptance index higher than $80 \%$, and the sausage with $6 \%$ of pomace had an index of approximately $70 \%$. Therefore, the addition of $3 \%$ of malt pomace to the sausage was the best alternative, since it had good acceptance by consumers, and provided an increased nutritional value. The results obtained in the present study showed that the use of malt pomace in meat products helps both to reduce production costs and solve an environmental issue. Moreover, the addition of this by-product meets consumer requirements, as they seek for healthier food products with higher nutritional values.

\section{References}

Aliyu, S., \& Bala, M. (2011). Brewer's spent grain: a review of its potentials and applications. African Journal of Biotechnology, 10(3), 324-331. http://dx.doi.org/10.5897/AJBx10.006

Almeida, A. R., Geraldo, M. R. F., Ribeiro, L. F., Silva, M. V., Maciel, M. V. O. B., \& Haminiuk, C. W. I. (2017). Bioactive compounds from brewer's spent grain: phenolic compounds, fatty acids and in vitro antioxidant capacity. Acta Scientiarum. Technology, 39(3), 269-277. http://dx.doi.org/10.4025/actascitechnol.v39i3.28435

Associação Brasileira da Indústria da Cerveja - CERVBRASIL. (2018). Mercado cervejeiro. Retrieved in 2019, October 27, from http://www.cervbrasil.org.br/novo_site/mercado-cervejeiro

Association of Official Analytical Chemists - AOAC. (2012). Official methods of analysis of AOAC International (19th ed.). Gaithersburg: AOAC International.

Bazargani-Gilani, B., Aliakbarlu, J., \& Tajik, H. (2015). Effect of pomegranate juice dipping and chitosan coating enriched with Zataria multiflora Boiss essential oil on the shelf-life of chicken meat during refrigerated storage. Innovative Food Science \& Emerging Technologies, 29, 280-287. http://dx.doi.org/10.1016/j.ifset.2015.04.007

Bezerra, M. V. P., Abrantes, M. R., Silvestre, M. K. S., Sousa, E. S., Rocha, M. O. C., Faustino, J. G., \& Silva, J. B. A. (2012) Avaliação microbiológica e físico-química de linguiça toscana no município de Mossoró, RN. Arquivos do Instituto Biológico, 79(2), 297-300. http://dx.doi.org/10.1590/S1808-16572012000200021

Borrajo, K. H. T., Lima, C. G., \& Trindade, M. A. (2016). Saciedade subjetiva, aceitação sensorial e aspectos tecnológicos de salsicha com adição de fibra de trigo. Brazilian Journal of Food Technology, 19(0), 1-8. http://dx.doi.org/10.1590/19816723.0816

Brasil. Ministério da Agricultura Pecuária e Abastecimento - MAPA. (2009, junho 4). Regulamento da lei n 8.918 , de 14 de julho de 1994 (Decreto n 6.871, de 04 de junho de 2009). Diário Oficial [da] República Federativa do Brasil, Brasília.

Brasil. Ministério da Agricultura Pecuária e Abastecimento - MAPA. (2020). Anuário da cerveja - 2019. Brasília: MAPA. Retrieved in 2021, Abril 05 from https://www.gov.br/agricultura/pt-br/assuntos/inspecao/produtos-vegetal/publicacoes/anuarioda-cerveja-2019

Brasil. Ministério da Agricultura Pecuária e Abastecimento - MAPA. (2019). Ministério da Agricultura instala Câmara da Cerveja. Brasília: MAPA. Retrieved in 2020, December 4, from https://www.gov.br/pt-br/noticias/agricultura-epecuaria/2019/10/ministra-tereza-cristina-instala-camara-da-cerveja

Brasil. Ministério da Saúde. Agência Nacional de Vigilância Sanitária - ANVISA. (2003, dezembro 23). Regulamento Técnico Sobre Rotulagem Nutricional de Alimentos Embalados (Resolução - RDC n 360, de 23 de dezembro de 2003). Diário Oficial [da] República Federativa do Brasil, Brasília.

Choi, Y. S., Kim, H. W., Hwang, K. E., Song, D. H., Jeong, T. J., Kim, Y. B., Jeon, K. H., \& Kim, C. J. (2015). Effects of fat levels and rice bran fiber on the chemical, textural and sensory properties of Frankfurters. Food Science and Biotechnology, 24(2), 489-495. http://dx.doi.org/10.1007/s10068-015-0064-5

Cordeiro, L. G., El-Aouar, A. A., \& Gusmão, R. P. (2012). Caracterização do bagaço de malte oriundo de cervejarias. Revista Verde de Agroecologia e Desenvolvimento Sustentável, 7(3), 20-22. Retrieved in 2019, October 27, from http://revista.gvaa.com.br

Damodaran, S., \& Parkin, K. L. (2019). Química de alimentos de Fennema (5. ed.). Porto Alegre, RS: Artmed.

Dutcoski, S. D. (2015). Análise sensorial de alimentos (4. ed.). Curitiba, PR: Champagnat.

Food and Agriculture Organization - FAO. (1995). Codex Alimentarius Comission: report of the fourteenth session of the codex commitee on fats and oils (21st ed). Roma: FAO.

França, T. Y. S., Faria, R. A. P. G., Oliveira, L. C. P., Santos, J. A., \& Oliveira, K. S. (2016, outubro 24-27) Determinação da composição bromatológica parcial de quibe elaborado a partir do resíduo cervejeiro (rc) adicionado de biomassa da banana verde (bbv). In XXV Congresso Brasileiro de Ciência e Tecnologia de Alimentos. Porto Alegre: UFRGS. 
Gois, F. D., Sbardella, M., Lima, C. B., Migotto, D. L., Cairo, P. L. G., Garbossa, C. A. P., Racanicci, A. M. C., \& Costa, L. B. (2017). Dietary Brazilian red pepper essential oil on pork meat quality and lipid oxidation. Ciência Rural, 47(2), 1-7. http://dx.doi.org/10.1590/0103-8478cr20160127

Hugo, C. J., \& Hugo, A. (2015). Current trends in natural preservatives for fresh sausage products. Trends in Food Science \& Technology, 45(1), 12-23. http://dx.doi.org/10.1016/j.tifs.2015.05.003

Instituto Adolfo Lutz - IAL. (2008). Métodos físico-químicos para análise de alimentos (4. ed.). São Paulo: IAL.

Lemos, A. N. S. C., \& Yamada, E. A. (2003). Princípios do processamento de embutidos cárneos. Campinas: CTC/ITAL.

Madubuike, P. C., \& Okolo, T. C. (2016). Quality estimation of brewer's spent grains and its potential: a product of beer industries. International Journal of Engineering Science, 5(3), 21-25.

Marti-Quijal, F. J., Zamuz, S., Tomašević, I., Gómez, B., Rocchetti, G., Lucini, L., Remize, F., Barba, F. J., \& Lorenzo, J. M. (2019). Influence of different sources of vegetable, whey and microalgae proteins on the physicochemical properties and amino acid profile of fresh pork sausages. Lebensmittel-Wissenschaft + Technologie, 110, 316-323. http://dx.doi.org/10.1016/j.Iwt.2019.04.097

Mendes, A. C. G., Rettore, D. M., Ramos, A. L. S., Cunha, S. F. V., Oliveira, L. C., \& Ramos, E. M. (2014). Salames tipo Milano elaborados com fibras de subprodutos da produção de vinho tinto. Ciência Rural, 44(7), 1291-1296. http://dx.doi.org/10.1590/0103-8478cr20130389

Morado, R. (2017). Larousse da cerveja: a história e as curiosidades de uma das bebidas mais populares do mundo. São Paulo: Alaúde.

Mussatto, S. I., Dragone, G., \& Roberto, I. C. (2006). Brewer's spent grain: generation, characteristics and potential aplications. Journal of Cereal Science, 43(1), 1-14. http://dx.doi.org/10.1016/j.jcs.2005.06.001

Nagy, M., Semeniuc, C. N., Socaci, S. A., Pop, C. R., Rotar, A. M., Salagean, C. D., \& Tofana, M. (2017). Utilization of brewer's spent grain and mushrooms in fortification of smoked sausages. Food Science and Technology (Campinas), 37(2), 315-320. http://dx.doi.org/10.1590/1678-457x.23816

Oliveira, D. F., Coelho, A. R., Burgardt, V. C. F., Hashimoto, E. H., Lunkes, A. M., Marchi, J. F., \& Tonial, I. B. (2013). Alternativas para um produto cárneo mais saudável: uma revisão. Brazilian Journal of Food Technology, 13(3), 163-174. http://dx.doi.org/10.1590/S1981-67232013005000021

Oliveira, M. J., Araújo, W. M. C., \& Borgo, L. A. (2005). Quantificação de nitrato e nitrito em linguiças do tipo frescal. Food Science and Technology (Campinas), 25(4), 736-742. http://dx.doi.org/10.1590/S0101-20612005000400018

Ordóñez, J. A. (2005). Tecnologia de alimentos: alimentos de origem animal. Porto Alegre: Artmed.

Özvural, E. B., Vural, H., Gökbulut, I., \& Özboy-Özbas, Ö. (2009). Utilization of brewer's spent grain in the production of Frankfurters. International Journal of Food Science \& Technology, 44(6), 1093-1099. http://dx.doi.org/10.1111/j.13652621.2009.01921.x

Petersson, K., Godard, O., Eliasson, A. C., \& Tornberg, E. (2014). The effects of cereal additives in low-fat sausages and meatballs. Part 2: rye bran, oat bran and barley fibre. Meat Science, 96(1), 503-508. PMid:24008058.

http://dx.doi.org/10.1016/j.meatsci.2013.08.019

Pintado, T., Herrero, A. M., Jiménez-Colmenero, F., Pasqualin Cavalheiro, C., \& Ruiz-Capillas, C. (2018). Chia and oat emulsion gels as new animal fat replacers and healthy bioactive sources in fresh sausage formulation. Meat Science, 135, 6-13. PMid:28843146. http://dx.doi.org/10.1016/j.meatsci.2017.08.004

Polizer, Y. J., Pompeu, D., Hirano, M. H., Freire, M. T. A., \& Trindade, M. A. (2015). Development and evaluation of chicken nuggets with partial replacement of meat and fat by pea fibre. Brazilian Journal of Food Technology, 18(1), 62-69. http://dx.doi.org/10.1590/1981-6723.4914

Qin, Y. Y., Zhang, Z. H., Li, L., Xiong, W., Shi, J. Y., Zhao, T. R., \& Fan, J. (2013). Antioxidant effect of pomegranate rind powder extract, pomegranate juice, and pomegranate seed powder extract as antioxidants in raw ground pork meat. Food Science and Biotechnology, 22(4), 1063-1069. http://dx.doi.org/10.1007/s10068-013-0184-8

Ramos, E. M., \& Gomide, L. A. M. (2007) Avaliação da qualidade de carnes: fundamentos e metodologias. Viçosa, MG: UFV. Rebello, F. F. P. (2009). Produção de cerveja. Revista Agrogeoambiental, 145-155.

Santos, J. I., Dinham, R., \& Adames, C. (2013). O essencial em cervejas e destilados (2. ed.). São Paulo, SP: Editora Senac.

Silva, D. P., Silva, T. S., Silva, A. D. P., Chagas Junior, A. F., \& Scheidt, G. N. (2013). Análise físico-química e sensorial de linguiça frescal mista de carne suína e caprina. Revista Verde de Agroecologia e Desenvolvimento Sustentável, 8(3), $239-246$. Retrieved in 2019, October 27, from http://revista.gvaa.com.br

Sisik, S., Kaban, G., Karaoglu, M. M., \& Kaya, M. (2012). Effects of corn oil and broccoli on instrumental texture and color properties of Bologna-Type sausage. International Journal of Food Properties, 15(5), 1161-1169. http://dx.doi.org/10.1080/10942912.2010.517339

United States Department of Agriculture - USDA. (2019). International baseline data. Retrieved in 2019, October 27, from https://www.ers.usda.gov/data-products/international-baseline-data/international-baseline-data 